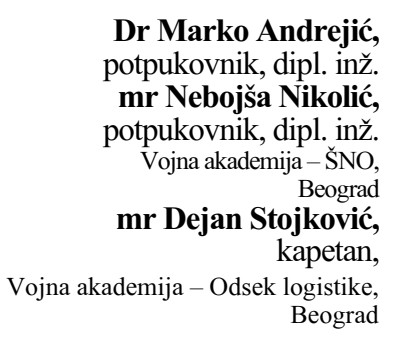

\section{LOGISTIČKA PODRŠKA LOGISTIČKIM OPERACIJAMA}

UDC: $355.42 / .43: 355.415$

Rezime:

U radu se razmatra logistička operacija i njena logistička podrška. Pored klasičnog pristupa operacijama, uvode se i odredene novine. Obrađuju se bitna obeležja logističkih operacija, ističu funkcije i zadaci logističke podrške, preporuke za kvalitetnu logističku podršku i njeni principi. Obrađuje se i naglašava značaj planiranja i upravljanja logističkom podrškom logističkim operacijama, i ukazuje na smer usavršavanja logističke podrške. Logistički sistem i operacija razmatraju se kroz čitav životni ciklus, a logistička podrška sa različitih aspekata. Naglašava se postupnost u rešavanju problema, primenjuje hijerarhijsko dekomponovanje, klasifikacija činjenica $i$ ističu težišta i prioriteti.

Ključne reči: logistička operacija, logistička podrška, planiranje, upravljanje.

\title{
LOGISTIC SUPPORT OF LOGISTIC OPERATIONS
}

Summary:

The paper treats logistic operation and its logistic support Certain new moments are introduced into the classical approach to logistic operations Besides the fundamental characteristics of logistic operations, the paper gives logistic support functions and tasks as well as its principles and recommendations for rising its quality. The importance of planning and managing logistic support of logistic operations is stressed, with the accent on tendencies in its improvement. Logistic systems and operations are followed through their life cycles while logistic support is treated from different aspects. Hierarchical decomposition and data classification are applied. Successivity in problem solving is pointed out as well as main points and priorities.

Key words: logistic operation, logistic support, planning, managing.

\section{Uvod}

U našoj novijoj teoriji i praksi logističke operacije nisu dovoljno istraživane, a ni definisane, ni sa organizacionog ni sa tehnološkog aspekta. Samim tim i logistička podrška logističkim operacijama nedovoljno je razmatrana u našoj teoriji i praksi. Određena iskustva stečena tokom agresije NATO-a na SRJ, potrebe prakse, zahtevi vremena i savremeni trendovi u razvoju vojnih nauka ukazali su na potrebu da se ovaj segment više rasvetli.

Logistička podrška logističkim operacijama ne može se istraživati i u praksi sprovoditi ako se ne poznaju bitna obeležja logističke operacije. Pravovremeno donošenje odluke o početku logističke operacije ključ je za njenu kvalitetnu realizaciju i logističku podršku. Preuranjene odluke mogu izazvati određene negativne implikacije u javnom mnjenju, a zakasnele odluke nisu dovoljno svrsishodne. 
Da bi se donela blagovremena i svrsishodna odluka o početku izvođenja logističke operacije, neophodno je znati za koje se vreme željenom dinamikom može realizovati (određene vrste i obima), uz moguća ometanja, sa raspoloživim resursima i mogućom logističkom podrškom, uz poštivanje propisane organizacije i tehnologije izvršavanja zadataka i uvažavanje promena intenziteta izvođenja logističke operacije u vremenu. Nekada će ta činjenica zahtevati obezbeđenje dodatnih resursa ili odustajanje od nekih zadataka. Određivanje tog vremena ozbiljan je posao koji se mora uraditi u miru i predočiti donosiocima odluka.

Kvalitetne pripreme za izvođenje logističke podrške operaciji vrlo su važan preduslov za njenu uspešnu realizaciju, a u okviru priprema poseban značaj zaslužuje planiranje. U toku izvođenja logističke operacije jedan sistem, angažovanjem svojih resursa, realizuje osnovnu delatnost $\mathrm{i}$ istovremeno je podržava, pa je u ovoj fazi vrlo bitno upravljanje njenom realizacijom i upotrebom resursa.

Pri razmatranju logističke operacije i njene logističke podrške primenjivaće se izvesna analogija sa klasičnim operacijama, ali će se koristiti i pristup primereniji postojećem tehničko-tehnološkom razvoju, zasnovan na određenim dostignućima projekt-menadžmenta i organizacionih nauka. Informacija o ceni izvođenja operacije na predviđeni način i ceni njene logističke podrške sve češće će se, pod uticajem javnosti, tražiti od donosioca odluka i planera operacije.

Određeni aspekti i segmenti logističke podrške logističkim operacijama u ovom radu su uopšteni, a oslanjaju se na iskustva autora, na istraživanja u kojima su učestvovali i na dostupne izvore. Navedeni pristup omogućava veću generalnost izrečenih stavova, a, s druge strane, može dobiti i na snazi (dubini i preciznosti) ukoliko se valjano operacionalizuje na svaki konkretan slučaj.

\section{Osnovna obeležja logističkih operacija}

Logistička operacija se izvodi prema jedinstvenom planu, na određenom prostoru i u određenom vremenu, radi dostizanja određenih ciljeva, ostvarenjem rezultata i izvršavanjem zadataka. Aspekti oblikovanja ciljeva logističke operacije, u zavisnosti od konkretnih okolnosti, jesu: vojni, tehničko-tehnološki, ekonomski, društveno-politički, ekološki, i dr. Izvođenje logističke operacije može se odvijati u različitim uslovima: društveno-političkim, bezbednosnim (mir, krizna stanja, mobilizacija, rat), vremenskim, prostornim, ekonomskim, i dr. Izvođenje može biti vezano za teritoriju matične države ili izvan matične teritorije.

Zajednička obeležja svih logističkih operacija jesu: cilj, rokovi (vreme), kompleksnost, obim zadataka, resursi (kadar, materijalna sredstva, prostor), organizaciona struktura, informacioni i kontrolni sistem, nivo komandovanja koji je planira, organizuje, izvodi i njome komanduje pri realizaciji.

Osnovni elementi logističke operacije, kao složene radnje (projektnog tipa), jesu: aktivnosti; vreme; resursi (kadrovski, materijalni, prostorni, informacioni, energetski i dr.) i troškovi (novac). Pri razmatranju kadrovskih resursa neophodno je izdvojiti kadrove koji upravljaju (upravljačka struktura); koji izvode ope- 
raciju, koji pružaju zaštitu (borbenu) i koji pružaju logističku podršku.

Opšte karakteristike logističke operacije su: osnovno je sredstvo za ostvarenje određenih ciljeva; objekat je izuzetne pažnje protivnika koji će nastojati da je oteža i spreči na sve moguće načine; složena je i dinamična pojava sa vrlo složenom tehnologijom izvođenja; velikih je razmera (prostor, angažovani resursi, upravljački nivoi, ...); permanentno vrednovanje i izražavanje težišta i prioriteta; visok intenzitet izvođenja; veoma brzo trošenje snaga i sredstava; veliko naprezanje ljudstva i tehnike, a moguć je (u slučaju iznenađenja i kasno donete odluke) i veliki procenat gubitaka u živoj sili i materijalnim sredstvima i nepovoljna struktura gubitaka; nastoji da se izvede do kraja bez promene prvobitne zamisli.

Za logističku operaciju, kao složenu aktivnost, karakteristična su dva vremenska perioda - priprema i realizacija. Svakom od ovih perioda treba obezbediti adekvatnu logističku podršku.

Pripreme za realizaciju logističke podrške operaciji obuhvataju opšte i neposredne pripreme. U okviru opštih priprema za odbranu zemlje i postupanja u kriznim situacijama treba, sa svih aspekata, razmatrati i logističke operacije kao realnu mogućnost, pripremati se za njihovu realizaciju i logističku podršku. U ovoj fazi vrlo je bitno sagledati cenu izvođenja operacije po svim funkcijama, subjektima angažovanja i objektima logističkog razmatranja, pri čemu logističke objekte i subjekte treba posmatrati kroz čitav životni ciklus (problemi nakon izvođenja operacije, mogući invaliditet ljudstva, zbrinjavanje porodica, $\mathrm{i}$ dr.).

Neposredna priprema, po svim funkcionalnim oblastima operacije, traje od momenta prijema direktive (zapovesti, zadat- ka...) za izvođenje operacije do početka izvođenja operacije. U ovoj fazi vrlo je bitno sagledati uticaj okruženja (pretnje i šanse), predvideti i prognozirati zahteve koji se generišu prema logističkoj podršci, mogućnosti logističke podrške i na osnovu toga doneti adekvatne odluke i izraditi kvalitetne planove (dokumente). U toku pripreme (planiranja) treba projektovati i snage za izvođenje operacije i snage za zaštitu izvođenja i snage za logističku podršku, a što zahteva kvalitetan kvantitativni prilaz rešavanju problema.

Izvođenje operacije uslovljeno je brojnim faktorima i elementima situacije. Tehnologija izvođenja operacije vrlo je složena i podrazumeva: grupisanje resursa (jedinica - snaga) za izvođenje operacije $u$ prostoru i vremenu, po organizacionim oblicima i celinama; dinamiku pretpočinjavanja i pridavanja jedinica (formiranih struktura) i resursa tokom izvođenja operacije; dinamiku dejstva i kretanja elemenata borbenog rasporeda (snaga i sredstava) u vremenu i prostoru; dinamiku trošenja resursa (goriva, municije, ...) u vremenu i prostoru; dinamiku nastajanja gubitaka u živoj sili, u vremenu i prostoru; otkaze i oštećenja TMS po mestu, vremenu, vrsti i obimu; vremenske norme trajanja određenih tehnoloških aktivnosti. Produžetkom trajanja operacije mogu se javiti određene operativne krize, pa je opšti trend na skraćenju vremena izvođenja logističke operacije.

\section{Funkcije, karakteristike i principi logističke podrške}

Logistička podrška predstavlja operacionalizaciju opštih postavki teorije i prakse logistike (veština i nauka upra- 
vljanja i inžinjeringa) u organizaciji Vojske. Kao poseban sistem obezbeđuje da se usklađenim odnosom, organizacijom i angažovanjem logističkih službi realizuje materijalna, zdravstvena i infrastrukturna podrška Vojsci. U skladu s tim, pod pojmom logistička podrška logističkoj operaciji će se, u daljem izlaganju, podrazumevati neposredno obezbeđenje i podrška (materijalna, zdravstvena, tehnička i infrastrukturna) logističkoj operaciji, kao osnovnoj delatnosti koja se sprovodi angažovanjem određenih resursa logističkog sistema. Važno je uočiti da deo zadataka iz domena logističke podrške logistički organi propisuju, a sprovode ostali subjekti odbrane.

Objektni cilj logističke podrške logističkoj operaciji jesu: proizvodnja, radovi i usluge radi podmirenja pojedinačnih, zajedničkih i opštih potreba snaga koje učestvuju u logističkoj operaciji (snage za izvođenje, snage za zaštitu i snage za logističku podršku), u domenu materijalno-tehničke, zdravstvene, infrastrukturne i finansijske podrške. Namenski cilj logističke podrške jeste: stvaranje efikasnih i efektivnih (vojnih) snaga koje učestvuju u logističkoj operaciji i njihova materijalno-tehnička, zdravstvena, infrastrukturna i finansijska podrška.

Logistička podrška uključuje sledeće grupe srodnih aktivnosti: proizvodnju, nabavku i prodaju, snabdevanje, održavanje, ishranu, odevanje, obezbeđenje energentima za zagrevanje prostorija, obezbeđenje električne energije, logističke uslužne delatnosti, zdravstvenu zaštitu, saobraćaj i transport, veterinarsku zaštitu, građevinarstvo, zaštitu od požara i finansiranje. Navedene logističke funkcije i zadaci realizuju se angažovanjem re- sursa vojske i resursa ostalih snaga odbrane, u pripremi i tokom sprovođenja logističkih operacija. Kvalitetna logistička podrška operaciji podrazumeva i poštovanje pri izvršavanju logističkih zadataka, mera zaštite na radu i zaštite životne sredine.

Organizacija i tehnologija pripreme i izvođenja logističke operacije, opšti uslovi pripreme i realizacije logističke operacije, prostorni i vremenski uslovi, opšte stanje u sistemu i okruženju (eksternom i internom), moguća dejstva protivnika, vrsta $i$ obim angažovanih resursa i vrsta logističke operacije, opredeljuju i konkretne oblike, obim, mesto, vreme, način, angažovane resurse $\mathrm{i}$ intenzitet realizacije logističke podrške pripreme i izvođenja logističke operacije. Logistička podrška logističkim operacijama predstavlja samo jedan poseban - specifičan slučaj logističke podrške, primeren uslovima u kojima se realizuje operacija i angažovanim snagama i sredstvima.

Za realizaciju logističke podrške logističkoj operaciji može se koristiti postojeći logistički (organizaciono-ekonomski) sistem (sastavljen od resursa logističkih službi organizovanih na ustaljeni način), a može se stvoriti i novi sistem. Pri kreiranju sistema za logističku podršku logističkoj operaciji, i pri izvršavanju zadataka logističke podrške, neophodno je pridržavati se određenih zakona i principa - organizacionih i ekonomskih.

Organizacioni principi su pravila (norme) kojima se rukovodi tvorac organizacionog sistema pri njegovom konstituisanju, odnosno korisnik sistema pri njegovom funkcionisanju. Njihovu suštinu i sadržinu čine organizacione mere kojima se utiče na optimalno ponašanje. 
Organizacioni principi kojih se treba pridržavati pri dostizanju organizacionih ciljeva podrazumevaju: principe cilja; principe konstitucije sistema (strukturalne i funkcionalne); principe funkcionisanja $\mathrm{i}$ principe organizacije rada (individualnog i kolektivnog).

Ekonomski principi predstavljaju pravila (norme) kojima se podvrgava ponašanje sistema koji realizuje logističku podršku operaciji, kako bi se što potpunije ostvarili ciljevi sistema. Osnovni ekonomski princip glasi: ostvariti maksimalne rezultate (izlaze iz sistema) uz minimalna ulaganja (ulaze u sistem). Stepen ostvarenja ovog principa u praksi se ispoljava kao kvantitativni izraz ostvarenog kvaliteta zadatka, odnosno kvantitativni izraz ostvarenog uspeha. Na delimičnim (parcijalnim) odnosima između izlaza iz sistema i ulaza u sistem takođe počivaju određeni principi, samo što su oni parcijalni: produktivnost, ekonomičnost i rentabilnost.

Uspešna logistička podrška operaciji mora biti efikasna i efektivna. Da se postigne uspešnost neophodno je balansiranje ova dva efekta radi obezbeđenja osnove za uspeh operacije. Dobro poznavanje ciljeva i karakteristika kvalitetne logističke podrške su osnova za određivanje principa na kojima ce se graditi i funkcionisati sistem logističke podrške.

Karakteristike kojima se odlikuje efikasna i efektivna logistika su: prognoziranje, integracija, neprekidnost, blagovremeni odziv i improvizacija.

Prognoziranje zahteva je značajno, za postizanje inicijative i za sinhronizaciju aktivnosti tokom realizacije zadataka. Kurs događaja ne može se nikad pouzdano odrediti, ali se zahtevi moraju što tačnije prog- nozirati. Da bi se podrška realizovala u potrebnoj meri po mestu, vremenu i načinu, neophodno je da se prepoznaju potrebe, akumulira i održava materijal i raspolaže kvalitetnim informacijama.

Integracija podrazumeva potpunu usaglašenost plana logističke operacije i plana logističke podrške logističkoj operaciji radi njenog uspeha. Integracija u procesima planiranja obezbeđuje, timskim radom, podršku tokom izvođenja operacija. Mogućnost da se izvrše logistički zadaci zavisi, u velikoj meri, od kvalitetnih planova. Integracija uključuje i standardizaciju i kompatibilnost opreme svih učesnika, kao preduslov za uspeh operacije.

Neprekidnost zahteva stalno svrsishodno odvijanje logističkih aktivnosti potrebnim intenzitetom. Obezbeđuje se na više načina: izborom i obezbeđenjem više izvora popune i načina realizacije zadataka, elastičnom promenom prioriteta $\mathrm{u}$ vremenu, u skladu sa nastalom situacijom, isturanjem logističke podrške, redukcijom potrošnje i stalnim balansiranjem troškova i rizika.

Blagovremeni odziv podrazumeva spremnost sistema koji vrši logističku podršku da reaguje u pravo vreme i kada se aktivnosti ne odvijaju po predviđenoj dinamici. Promena prvobitno uspostavljene organizacije i organizovanje prema zadatku nekada su neophodni radi brzog reagovanja na narasle zahteve i osiguranje uspeha. Eksploatacija taktičkih i operativnih uspeha nekada zahteva privremeno narušavanje dugoročnih planova, promenu lokacije snaga - jedinica koje vrše logističku podršku, isturanje resursa za zdravstvenu podršku i slično.

Blagovremeni odziv je moguć ako su ispunjeni sledeći uslovi: izražen kvalitetan sistem za logističku podršku sa efi- 
kasnom organizacijom, kvalitetno planiranje, dobra obučenost ljudstva i čvrsto komandovanje. Kada su logistički resursi ograničeni, a vreme za realizaciju zahteva kratko (što je čest slučaj), blagovremenost odziva sistema, u velikoj meri zavisi od pouzdanih tokova informacija.

Improvizacija se javlja kao potreba logističkog sistema da se prilagodi promenama stanja okruženja. Predstavlja sposobnost da se učini, postavi, aranžira ili proizvede ono što je potrebno pomoću onoga čime se raspolaže, odnosno onoga što je trenutno dostupno. Primenjuje se radi obezbeđenja neprekidnosti logističke podrške u situacijama kada to ne može da se postigne standardnim propisanim procedurama (zbog dejstva protivnika, destrukcije resursa, poremećaja u lancu snabdevanja, vremenskih nepogoda i sl.). Kvalitetna logistička improvizacija može obezbediti uspeh, a loša improvizacija dovesti do neuspeha operacije.

U skladu sa navedenim karakteristikama logistike na operativnom nivou, za kreiranje sistema logistike i propisivanje regulative treba da se ispoštuju sledeći principi: logistička obaveštenost; postavljanje cilja; plodonosna logistika; međuzavisnost; jednostavnost; blagovremeni odziv; zamah; efikasnost i sigurnost.

Osnovni kriterijumi valjanosti logističke podrške su: logistička efektivnost, ekonomičnost, racionalnost, rentabilnost, potpunost, pravovremenost i sigurnost.

\section{Planiranje logističke podrške logističkoj operaciji}

Planiranjem izvođenja logističke operacije i njene podrške potrebno je da se iznađu rešenja za najnepovoljnije uslove izvođenja operacije. Pri sagledavanju mogućih varijanti logističke podrške treba uvažavati kriterijume: ekonomičnosti, minimalnog rizika, minimalnog faktora, elastičnosti i fleksibilnosti. Pri donošenju odluke o izboru određene varijante rešenja, treba stalno imati na umu područje slobode izbora koje je određeno faktorima na koje se ne može uticati i kojima se mora prilagoditi, kao i faktorima na koje se može uticati.

Faze logističke operacije i planiranja logističke podrške operacije obuhvataju planiranje logističke podrške pripremama za logističku operaciju i planiranje logističke podrške izvođenju logističke operacije.

Pri planiranju logističke podrške logističkim operacijama uočavaju se tri grupe problema: problemi koji se mogu uspešno rešavati pomoću formalizovanih postupaka (algoritama); problemi koji se mogu na zadovoljavajući način rešavati korišćenjem savremenih tehnologija (softver, hardver, netver); problemi koji se mogu rešavati zahvaljujući ljudskom potencijalu, specifičnom znanju, emocijama, iskustvu, intuiciji i sposobnosti da se brzo identifikuju ključni činioci i pretraže moguće varijante u nestandardizovanim problemima.

Elementi koji se razmatraju pri planiranju logističke podrške su zadaci - aktivnosti (određivanje logičke međuzavisnosti aktivnosti i određivanje protoka izlaznih parametara prethodne aktivnosti $u$ ulazne parametre kod narednih aktivnosti) koji se odnose na logističku podršku operacije i na upotrebu logističkih organa i jedinica, resursi (od interesa za logističku podršku operacije) i rokovi realizacije aktivnosti (početak, završetak, trajanje). 
Resursi za logističku podršku operacije su ograničeni, pa je neophodno da se reši problem njihovog optimalnog raspoređivanja, $i$ da se postavi informaciona osnova za njihovo obezbeđenje po količini, kvalitetu i rokovima. Suština optimalne raspodele ograničenih resursa, $u$ funkciji vremena, na izvršenje bilo koje aktivnosti, projektuje se na određivanje vremena početka svake aktivnosti, koje pri zadatim ograničenim resursima obezbeđuje izvršenje zadatka u najkraćem roku, pri čemu se u obzir uzima tehnološka zavisnost aktivnosti. Optimalno rešenje angažovanja resursa uslovljeno je usvojenim kriterijumom optimizacije i prisutnim ograničenjima (ograničavajućim uslovima), a može se vršiti uz uvažavanje sledećih kriterijuma: da se za čvrsto zadati rok, uz poznati obim i vrstu zadataka, iznađe optimalni plan angažovanja resursa (uključujući i snage za komandovanje, snage za realizaciju i snage za zaštitu operacije); da se za čvrsto zadate resurse, poznati obim i vrstu zadataka iznađe minimalno trajanje izvršenja zadatka; da se za poznate raspoložive resurse $u$ zadatom intervalu iznađe vrsta i obim zadataka koje je moguce realizovati uz postizanje maksimalnih efekata (ekonomskih i drugih).

Dimenzije planiranja logističke podrške logističkoj operaciji jesu: prostorna, vremenska i organizaciono-tehnološka. Prostorna dimenzija podrazumeva odvijanje određenih aktivnosti iz domena logističke podrške na određenom prostoru koji je određen mestom lociranja resursa koji su predmet logističke operacije, i rasporedom snaga koje vrše logističku podršku. Prostornu dimenziju je, pri izradi planskih rešenja, najbolje predstaviti na topografskoj karti na koju su uneti razmeštaj bitnih elemenata i važni podaci, skice i šeme. Vremenska dimenzija planiranja ukazuje na to da svaka aktivnost ima određeno trajanje i da se mora odvijati $\mathrm{u}$ određenom vremenu, $\mathrm{u}$ odnosu na određene vremenske repere i ograničene materijalne i ljudske resurse. Ova dimenzija planiranja najbolje se izražava linijskim dijagramima aktivnosti - gantogramima aktivnosti. Organizaciono-tehnološka dimenzija podrazumeva odvijanje aktivnosti na način i u vremenu određenom njenim logičnim mestom u okviru zadatka, odnosno cele operacije. Predstavlja se mrežnim planom, podržanim linijskim dijagramima $\mathrm{i}$ određenim slobodnim formama deskripcije (opisno). Terminski mrežni plan, kao instrumentarij za određivanje tehnologije izvođenja logističke podrške operacije, treba da pruža informacije o: zadacima i njihovim nosiocima; terminiranju zadataka; raspodeli resursa po zadacima i ulazno-izlaznim parametrima aktivnosti (tamo gde je to potrebno).

Pri planiranju logističke podrške moraju se uzeti u obzir sledeća ograničenja: odluka rukovodstva (komandanta) za operaciju; izraženi zahtevi angažovanih subjekata i snaga; orijentaciono odobrena materijalna sredstva - resursi stavljeni na raspolaganje (po vrstama, strukturi, mestu i vremenu) za izvršenje zadatka; orijentaciono odobren kadar - stavljen na raspolaganje; obim i struktura resursa koje dodeljuje pretpostavljena komanda; obim i struktura resursa (svih vrsta) teritorije, po logističkim funkcijama, stavljenih na raspolaganje; cena odluke za izvođenje operacije na predviđeni način (procenjeni - očekujući gubici žive sile (po strukturi), procenjeni - očekujući gubici i oštećenja materijalnih sredstava (po vr- 
stama, strukturi, mestu i vremenu nastajanja); stanje po logističkoj podršci i stvarne (praktične - prave) logističke mogućnosti sastava koji realizuje logističku operaciju; tehnologija izvođenja operacije i logističke podrške i normativa koja reguliše efikasno i kvalitetno planiranje i rad komande (tima).

Planiranje logističke podrške logističkoj operaciji je kreativan stvaralački proces koji, s obzirom na suštinu, obuhvata misaono-stvaralačke aktivnosti i aktivnosti tehničkog karaktera.

Planiranje logističke podrške logističkoj operaciji obuhvata:

1. Definisanje scenarija u kojem bi se operacija izvodila.

2. Planiranje preventivnih mera za osiguranje sprovođenja logističke podrške, umanjenje i otklanjanje negativnih posledica okruženja i elemenata situacije.

3. Planiranje zadataka (proizvodnja, radovi i usluge) logističke podrške (vrsta, obim, način realizacije, trajanje).

4. Planiranje potrebnih kadrova za sprovođenje logističke podrške.

5. Planiranje potrebne opreme, materijala i sitnog inventara za izvršenje zadataka (uključujući i opremu za rad, opremu za zaštitu ljudstva od padavina, niske i visoke temperature i opremu za zaštitu na radu).

6. Predviđanje mogućih uslova za izvršenje zadataka, relevantnih faktora $\mathrm{i}$ elemenata situacije.

7. Planiranje upravljanja logističkom podrškom.

8. Planiranje priprema za sprovođenje planova i rešenja logističke podrške.

9. Planiranje ažuriranja i korekcija planova i sadržaja koji regulišu logističku podršku operacije.
Čitav sistem planiranja logističke podrške logističkim operacijama zasniva se na sledećem redosledu: ciljevi rukovodstva (komandanta); predloženi plan upotrebe snaga zasnovan na definisanom scenariju izvođenja operacije, proceni protivnika i vlastitih mogućnosti; utvrđivanje opštih logističkih zahteva i koji su od njih odlučujući ili kritični; utvrđivanje obima i kvaliteta kritičnih snaga (VESova) i kritičnih materijalnih sredstava (transportna i manipulativna oprema, pogonska sredstva, UBS, energetska sredstva, itd.) i logističkih mogućnosti; sagledavanje posledica nedovoljnih količina materijalnih sredstava i nedovoljnih kapaciteta, za realizaciju logističkih zadataka, po osmišljenim varijantama dejstva; utvrđivanje poslova u logističkom i operativnom pogledu, da bi se ublažila oskudica ili prevazišle teškoće.

\section{Upravljanje logističkom podrškom logističkoj operaciji}

Upravljanje logističkom podrškom logističkoj operaciji predstavlja usmeravanje i koordinaciju ljudskih i materijalnih resursa, kako bi se podrška realizovala u planiranom vremenu, $u$ planiranom obimu, sa planiranim troškovima i bila planiranog kvaliteta. Njime se obezbeđuje jedinstveno postupanje i homogena akcija. Da bi se aktivnosti organizacionih procesa odvijale po zahtevanoj tehnologiji, i da bi se njima upravljalo, moraju se, u procesu planiranja, sagledati i osigurati svi potrebni ulazni i izlazni parametri organizacionih aktivnosti, što je prikazano na slici.

Problemi većine organizacionih sistema, u praksi, ne proizilaze iz organi- 


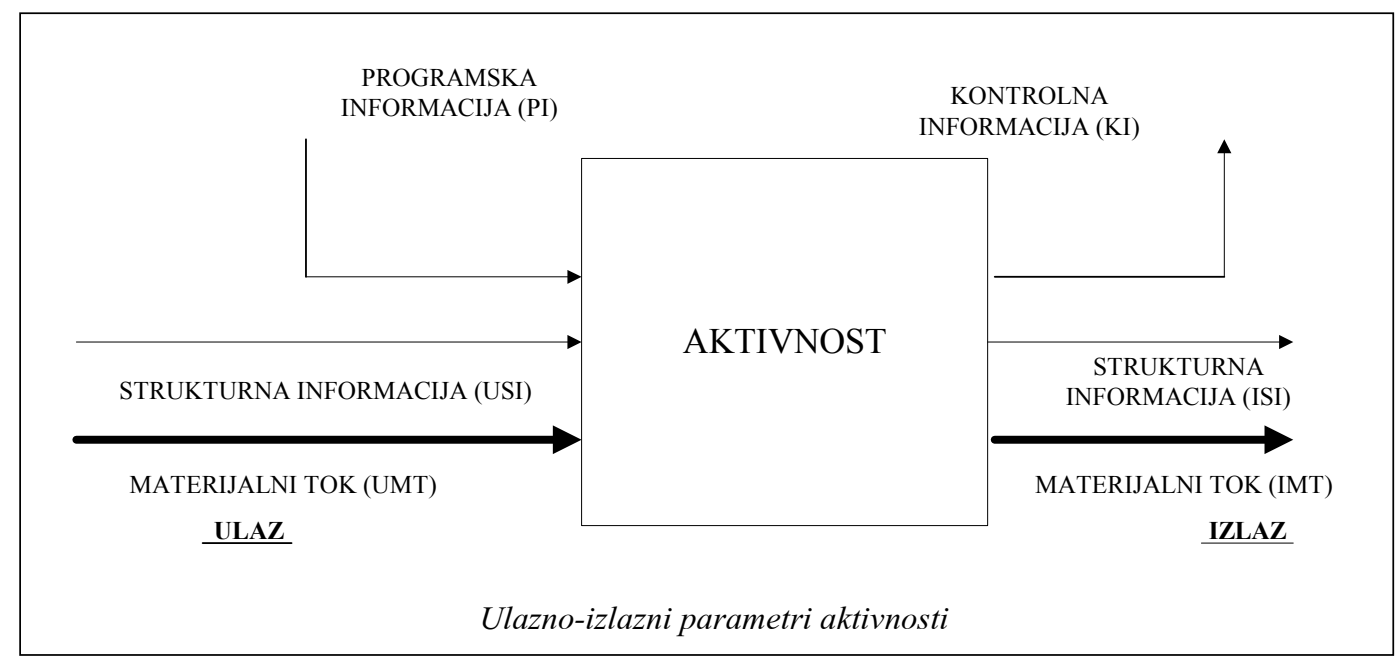

zacione, već iz procesne strukture, zbog nepovezanih aktivnosti procesa ili procesa međusobno. Tehnologija sprovođenja organizacionih procesa ne zasniva se samo na određivanju logičke međuzavisnosti aktivnosti, već i na određivanju protoka izlaznih parametara prethodne aktivnosti u ulazne parametre narednih aktivnosti. Da bi izvršioci mogli realizovati aktivnosti, neophodno je da imaju sve programske informacije, ulazne strukturne informacije i osiguran ulazni materijalni tok. Takođe, neophodno je da znaju kome treba da dostavljaju izlazne strukturne informacije, izlazne materijalne tokove i izveštaje.

Aktivnosti izvode pojedinci, grupe, tehnološke celine i ekipe koje su organizaciono, preko svojih rukovodstava, uvezani $\mathrm{u}$ određene organizacione celine $\mathrm{i}$ jedinice. Da bi svaka organizaciona celina ili pojedinac - izvršilac mogao da realizuje određene aktivnosti, neophodni su mu podaci i informacije. Takođe, i rukovodstvu koje upravlja kompletnim organizacionim procesom neophodne su određene informacije. Potrebne informacije obezbeđuju se kroz horizontalno i vertikalno informisanje.

Da bi se uspešno upravljalo sprovođenjem logističke podrške operaciji, neophodno je, na osnovu programa (organizacije i tehnologije) izvođenja, obezbediti sve potrebne informacije o planskim aktivnostima (programske informacije), kako bi se moglo narediti - aktivirati njihovo sprovođenje, i obezbediti da se pri kontroli sprovođenja aktivnosti dobiju projektovani izlazni parametri i rezultati aktivnosti koji se mogu upoređivati sa ulaznim parametrima. Uspešno odvijanje logističke podrške operacije zahteva obezbeđenje prenosa svih parametara i rezultata prethodnih aktivnosti u sledeće aktivnosti.

Ako u toku realizacije dođe do kasnijeg ili ranijeg završetka aktivnosti, neophodno je doneti odluku o daljem toku odvijanja aktivnosti i promeni koja se mora provesti (na primer, skraćenje aktivnosti na kritičnom putu ili raniji početak neke aktivnosti), odnosno promeniti programske informacije aktivnosti, a zatim sprovesti vertikalnu i horizontalnu informisanost. 


\section{Zaključak}

Logističke operacije postale su realnost i sve više dobijaju na značaju u teoriji i operativnoj praksi. Pristup njihovom razmatranju se modernizuje, uz primenu sistemskog i situacionog pristupa i savremenih tehnologija, a vrlo je važna i cena donete odluke po svim elementima i funkcijama (optimizacija utroška resursa). Pri tome se subjekti i objekti logističke operacije posmatraju kroz čitav životni ciklus.

Danas logističke operacije studiozno izučavaju i operativci i logističari, pri čemu je polazište da se mora obezbediti efikasna i efektivna logistička podrška njihovom izvođenju. Ključ za njihov uspeh jesu: veći udeo logističkog kadra u planiranju i upravljanju logističkom operacijom, pravovremeno donošenje odluke o početku izvođenja; kvalitetne pripreme sa naglašenim planiranjem; kvalitetno upravljanje $u$ fazi realizacije i kvalitetna logistička podrška pripremi i sprovođenju logističke operacije.

Logistički pristup logističkim operacijama i njihovoj podršci zahteva da se i sistem koji se logistički podržava aktivno odnosi prema vlastitoj logističkoj podršci, prilagođava njenoj strukturi, organizaciji i tehnologiji rada, resursima i mogućnostima. Sistem koji izvodi logističku operaciju biće kvalitetno podržan ako se pridržava organizacije i tehnologije logističke operacije i logističke podrške, logističkih ograničenja, kriterijuma, principa i odlika dobre logistike.

Poznavanje uslova izvođenja, organizacije i tehnologije izvođenja logističkih operacija, sistema logističke podrške vojske uopšte, funkcija i zadataka, nadle- žnosti, elemenata, principa, resursa i mogućnosti, organizacije i tehnologije logističke podrške, i načina funkcionisanja (u miru, mobilizaciji i ratu), polazna je osnova za uspešnu podršku logističke operacije. Naime, logistička podrška logističkim operacijama predstavlja samo jedan poseban - specifičan slučaj logističke podrške, primeren uslovima u kojima se realizuje operacija i angažovanim snagama i sredstvima.

Opšti uslovi pripreme i realizacije logističke operacije, prostorni i vremenski uslovi, opšte stanje u sistemu i okruženju (eksternom i internom), moguća dejstva protivnika, vrsta i obim angažovanih resursa i vrsta logističke operacije, opredeljuju i konkretne oblike, obim, mesto, vreme, način, angažovane resurse i intenzitet realizacije logističke podrške pripremi i izvođenju logističke operacije.

Opšti je trend u svetu da se proširuje spektar aktivnosti (puni spektar) koji uključuje logističku podršku, a odnosi se na podršku čoveka kao individue i organizacionog sistema kao celine. Od logističkog sistema zahteva se da obezbedi ono što je potrebno i podrži kada treba, tamo gde treba, u potrebnom obimu i na zahtevani način. Sve to zahteva izvesnu autonomiju (upravljačku i finansijsku) u razvoju i upotrebi sistema logističke podrške.

\footnotetext{
Literatura:

[1] Andrejić, M.; Maksić, R.; Nikolić, N.: Taktika TSl, recenziran udžbenik, GŠ VSCG UŠiO, Beograd, 2004 (štampanje udžbenika u toku).

[2] Iskustva jedinica službi Vojske Jugoslavije nivoa bataljona u borbenim dejstvima tokom suprotstavljanja agresiji NATO na SRJ (projekat), IRV SŠONID VJ, Beograd, 1999.

[3] Primena logističkog principa u organizovanju vojske (projekat), SLGS̆ VJ, Beograd, 2000.
} 
